\title{
The degradation behaviour of nickel-based superalloys in the medical waste incineration plant
}

\author{
SHAFAQ ASHRAF LONE and ATIKUR RAHMAN* \\ Department of Metallurgical and Materials Engineering, National Institute of Technology Srinagar, \\ Hazratbal, Srinagar 190006, India \\ e-mail: atikurrhmn@gmail.com
}

MS received 4 May 2019; revised 1 August 2019; accepted 5 August 2019

\begin{abstract}
The present work was aimed at analysing the oxidation behaviour of three nickel-based superalloysSuperni 718, Superni 75 and Superni 750, by conducting in-situ study in the secondary chamber of a medical waste incinerator at $800-850^{\circ} \mathrm{C}$ for $1000 \mathrm{~h}$. It was observed that among the three superalloys, Superni 75 is best suited for such an environment. This was concluded by comparing the weight change after $100 \mathrm{~h}$ for total $1000 \mathrm{~h}$, constituting 10 thermal cycles. The morphology of the oxide scale formed on the substrate was analysed using FE-SEM. The elemental composition was obtained by EDS. The depth profiling of the scale was done using the XPS technique. The chemical composition was also examined by the XRD analysis. The superior oxidation property of Superni 75 is due to the higher Ni-Cr content. The oxidation resistance of the nickel-based superalloys in the aggressive environment of medical waste incinerator is attributed to the presence of chromia oxide- $\mathrm{Cr}_{2} \mathrm{O}_{3}$ and spinel $\mathrm{NiCr}_{2} \mathrm{O}_{4}$.
\end{abstract}

Keywords. Nickel-based superalloys; hot corrosion; incinerator.

\section{Introduction}

Treatment of solid waste by incineration process has gained importance because of the limitation of available land space, the expense of land-filling and environmental concerns. The municipal wastes mainly include glass, metals, organics, paper, cardboard, plastics, textiles, wood, leather, rubber, linoleum, fine wastes, minerals, miscellaneous inorganics (ash, dirt, etc.) whereas the medical waste consists of infectious wastes, viruses causing diseases such as hepatitis B and AIDS, sharp objects, radioactive and chemical materials. Incineration was propounded to be useless due to the secondary waste stream produced, but with the equipments such as electrostatic precipitators and scrubbers, the secondary stream can be treated and thus rendered harmless. The incineration of the medical waste has many advantages associated with it. A complete destruction of the microorganisms can be achieved at around $1000^{\circ} \mathrm{C}$ and above. Incineration has successfully reduced the toxicity of medical waste $[1,2]$. Secondly, the heat produced by burning the waste can be used to generate electricity since the demand for electricity is rising in India with the increase in population. Globally the demand of electricity has significantly increased by $3.1 \%$.

*For correspondence

Published online: 04 October 2019
However, since their emergence, the efficiency of "Waste to Energy" plants has remained low. In order to increase its efficiency, the operating temperature is to be increased but increasing the operating temperature results in the increase in hot corrosion of the materials used in these plants, especially in the boiler components [3]. In addition to high temperature, fly ash of the corrosive species is produced in the incinerator during combustion of the waste, creating an aggressive environment and decreasing the life of the different components [4]. The fly ash can be in a semi-molten or a molten form, containing sulphates and chlorides of zinc and lead [5]. Since the molten chlorides have lower melting point, they are more often encountered. The low melting compounds lead to severe hot corrosion of the alloys. Analysis has shown the presence of various elements like $\mathrm{Ca}, \mathrm{Mg}, \mathrm{Al}, \mathrm{Si}, \mathrm{Na}, \mathrm{Cl}, \mathrm{S}, \mathrm{C}$ as well as oxygen in fly ash of medical waste incinerators leading to accelerated corrosion of metals [6]. The synergistic interaction of high temperature and corrosive incineration environment may lead to premature failure of various components [5-9].

An approach to minimize the problem of hot corrosion in the incinerator is to use suitable materials that are able to resist the aggressive environment while maintaining their properties. Deepa Mudgal et al compared the degradation of Ni-based superalloys, Superni-600 and Superni-718 with the cobalt-based superalloy, Superco-605 and found that the Ni-based superalloy showed better performance than the 
cobalt-based superalloy [4]. Nickel-based alloys containing chromium, aluminium and silicon have shown good corrosion resistance in $\mathrm{ZnCl}_{2}, \mathrm{PbCl}_{2}$ and $\mathrm{SnCl}_{2}$ environments [10]. Comparative studies in an actual environment are thus required to assess the performance of materials.

Most of the high temperature degradation studies have been carried out in simulated environment [10-19] and very few in-situ studies on superalloys have been carried out in a medical waste incinerator. Hence the aim of present study is to evaluate the degradation behaviour of nickel-based superalloys Superni-75, Superni-750 and Superni-718 hung inside the secondary chamber of a medical waste incinerator at SKIMS Hospital, Soura, Jammu and Kashmir, India which is a tertiary care 600 bedded teaching hospital, catering to the average socioeconomic class.

\section{Experimentation}

\subsection{Sample preparation}

Midhani grade superalloys-Superni 75, 750 and 718 were procured for the study. The composition was obtained by spark spectroscopy, shown in table 1 . Specimens of size $30 \times 30 \times 3(\mathrm{~mm})$ were cut and polished up to 800 grit size followed by cloth polishing to obtain mirror finish. To hang the specimens in the incinerator, a hole of diameter $3 \mathrm{~mm}$ was drilled at one corner in each specimen, in order to hang the specimens in the incinerator. The initial weight was carefully noted using the weighing balance of sensitivity $10^{-4} \mathrm{~g}$ (CA 224, Contech Mumbai).

\subsection{Corrosion study in the incinerator}

The investigation was carried out in the medical waste incinerator of SKIMS Hospital, Soura, Jammu and Kashmir, India. The capacity of the plant is $125 \mathrm{~kg} / \mathrm{h}$. Prepared samples were hung in the secondary chamber of the incinerator using stainless steel wire is shown in figure 1 . The temperature in the secondary chamber varies between 800 and $850^{\circ} \mathrm{C}$. The variation occurs due to the heterogeneous nature of the waste. The study was conducted for $1000 \mathrm{~h}$. The material of investigation was subjected to cyclic exposure. The samples were exposed to the

Table 1. Chemical composition of Superni 75, Superni 750 and Superni 718 , as obtained by the spark spectroscopy.

\begin{tabular}{llllllll}
\hline & \multicolumn{6}{c}{ Chemical composition, wt\% } \\
\cline { 2 - 7 } Midhani grade & $\mathrm{Ni}$ & $\mathrm{Fe}$ & $\mathrm{Cr}$ & $\mathrm{Ti}$ & $\mathrm{Mo}$ & $\mathrm{Nb}$ \\
\hline Superni 75 & Bal. & 3 & 19.5 & 0.3 & - & - \\
Superni 750 & Bal. & - & 16.45 & 1.70 & - & 1.20 \\
Superni 718 & Bal. & 19.8 & 17.6 & 0.96 & 3.23 & 4.91 \\
\hline
\end{tabular}

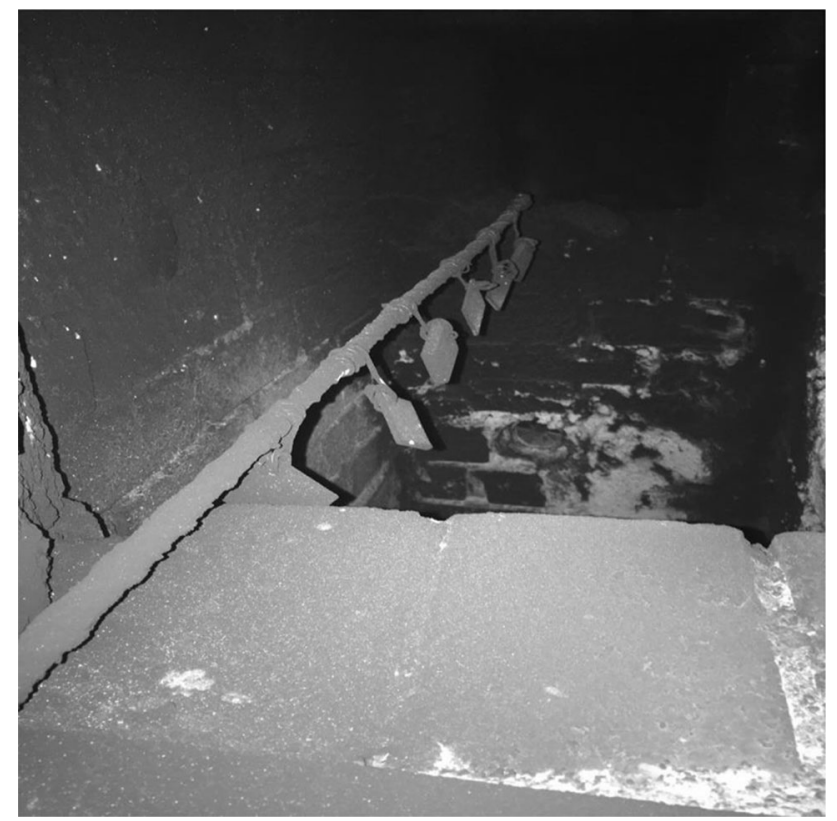

Figure 1. Photograph of the Superni 75, Superni 750 and Superni 718 samples hung in the secondary chamber of medical waste incinerator.

incinerator environment for $100 \mathrm{~h}$ followed by cooling in air for 30 minutes. This constituted one thermal cycle. After each thermal cycle, the change in weight was measured for thermogravimetric study and samples were visually examined.

After the exposure of $1000 \mathrm{~h}$, the surface of the oxidized samples was studied using scanning electron microscope (Model Hitachi S4700 at an accelerating voltage of $6 \mathrm{kV}$ and a current of $10 \mu \mathrm{A}$ ) and X-ray photoelectron spectroscopy (XPS).

XPS gives the real chemical composition depth distribution. A Kratos Axis Ultra spectrometer with a monochromated $\mathrm{AlK} \alpha \mathrm{X}$-ray source was employed in the XPS. The samples were exposed to the ultra-high vacuum in the XPS chamber before the analysis. Wide energy survey scans $(0-1300 \mathrm{eV})$ and the high resolution spectra of the elements were collected. The calibration of the binding energies obtained was done using adventitious carbon $(\mathrm{C} 1 \mathrm{~s})$ peak at $284.5 \mathrm{eV}$ as a reference. Shirley type background was used to examine the XPS peaks and nonlinear least square fitting of the experimental data based on mixed Gaussian/Lorentzian peak shape. The oxidized specimens were sectioned using EDM wire cut method, taking care of keeping the oxide layer undisturbed. To obtain the elemental information, Energy dispersive spectroscopy (EDS) was done with FE-SEM simultaneously. The phases formed in the oxide scale were identified using $\mathrm{X}$-ray diffraction (XRD-Model: EMPYREAN PANalyticalNetherlands).

The degradation behaviour was further studied by thermogravimetric measurements and metal thickness loss. 


\section{Results}

\subsection{Visual observations}

In case of Superni 75, initially after $100 \mathrm{~h}$ of exposure, a black scale was formed on the surface of the substrate. After $200 \mathrm{~h}$, some cream coloured patches started appearing with green coloured spots. The scale became light brown having green spots after $400 \mathrm{~h}$. After $500 \mathrm{~h}$, the colour changed to gray with brown patches. Upon the completion of $1000 \mathrm{~h}$ of exposure, two coloured regions were observed, one light gray and the other dark gray (figure 2a). Like Superni 75, in Superni 750 and Superni 718 , after $100 \mathrm{~h}$ the oxide layer formed was black in colour. From this it can be inferred that in nickel-based alloys, same type of oxide is being formed initially. However, in Superni 750, after $200 \mathrm{~h}$, it became dark gray with cream coloured patches. Spallation on the surface is evident. After $500 \mathrm{~h}$ the scale turned brownish with green patches. After $600 \mathrm{~h}$, gray colour was observed, showing that ash deposition had taken place. The gray colour got intensified up to $1000 \mathrm{~h}$ (figure 2b). In Superni 718, after $200 \mathrm{~h}$ the oxide was gray in colour with reddish brown patches. After $300 \mathrm{~h}$, there were cream coloured spots up to $500 \mathrm{~h}$, after which brownish colour with yellow spots was observed. Then the scale became dark gray with green patches. At the end of $1000 \mathrm{~h}$ the scale was mainly reddish brown with some yellow regions (figure 2c). Spallation can be clearly observed in this case.

\subsection{Gravimetric analysis}

The variation in weight has been plotted as weight change per unit area versus the number of exposure cycles, as shown in figure 3a. It can be clearly observed that the change in weight is highest in Superni 718 followed by Superni 750. The variation in weight is least in case of Superni 75. The parabolic rate constant ' $k p$ ' was calculated from the slope of linear regression line fitting in (weight change per unit area) ${ }^{2}$ versus the number of exposure cycles, as presented in figure $3 \mathrm{~b}$. In case of Superni 75, the $\mathrm{kp}$ value is $4.42 \times 10^{-8} \mathrm{mg}^{2} \mathrm{~cm}^{-4} \mathrm{~s}^{-1}$, for Superni $750 \mathrm{kp}$ is $6.68 \times 10^{-8} \mathrm{mg}^{2} \mathrm{~cm}^{-4} \mathrm{~s}^{-1}$ and in case of Superni 718 , $\mathrm{kp}$ is $18.07 \times 10^{-8} \mathrm{mg}^{2} \mathrm{~cm}^{-4} \mathrm{~s}^{-1}$. Up to $500 \mathrm{~h}$ Superni 718 deviates from parabolic law of oxidation $\left(\mathrm{R}^{2}=88.7\right)$, but after $500 \mathrm{~h}$ it follows parabolic law of oxidation as is evident from a decreased oxidation. Thus the oxidation resistance of Superni 75 is superior than Superni 750 which is in turn better than Superni 718, when exposed to incinerator environment for $1000 \mathrm{~h}$. The cumulative weight gain is shown in figure $3 \mathrm{c}$.

\section{$3.3 \mathrm{FESEM} / \mathrm{EDS}$ analysis}

The surface morphology of the oxidized samples after $1000 \mathrm{~h}$ of exposure in the secondary chamber of medical waste incinerator was analysed using FESEM/EDS. The FESEM micrographs are shown in figures $4 a-c$. The surface of Superni 75 (figure 4a) after exposure shows more uniform morphology with less number of defects as compared to Superni 750 (figure 4b) or Superni 718 (figure 4c). The surface of Superni 75 is covered by globular shaped particles, scattered throughout. The EDS elemental analysis shows the presence of oxygen, $\mathrm{Ca}, \mathrm{S}, \mathrm{Si}$ and $\mathrm{Mg}$ along with the substrate elements like $\mathrm{Ni}, \mathrm{Cr}$ and $\mathrm{Ti}$. The scale formed on Superni 750 is irregular exhibiting a flaky behavior. Voids and micro-cracks are observed on the surface. The elements like oxygen, $\mathrm{S}, \mathrm{Ca}, \mathrm{Mg}$ and $\mathrm{Si}$ have been detected along with the surface elements like $\mathrm{Cr}, \mathrm{Fe}, \mathrm{Ni}$ and $\mathrm{Ti}$ in Superni 750. In case of Superni 718, the surface appears to be covered with irregularly shaped particles with rodshaped structures. There are voids and spalled regions in the scale. The EDS analysis of the surface shows substrate elements like $\mathrm{Ni}, \mathrm{Fe}$ and $\mathrm{Ti}$ and the presence of oxygen, $\mathrm{Ca}$, $\mathrm{S}, \mathrm{Na}$ in major quantity and $\mathrm{Mg}, \mathrm{Si}$ and $\mathrm{Al}$ in minor quantity. The presence of these elements indicates the deposition of ash in the incinerator environment [4].

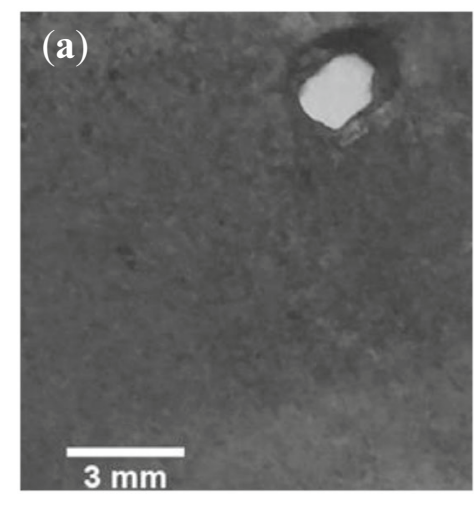

Superni 75

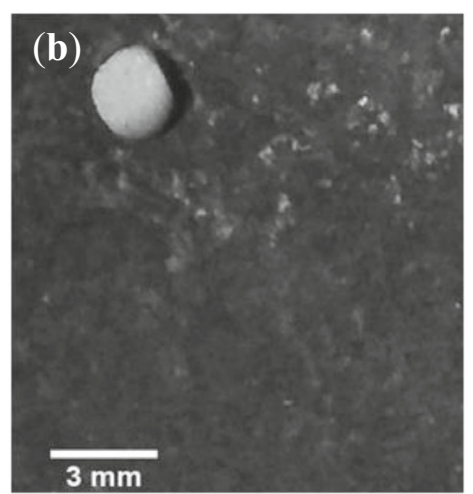

Superni 750

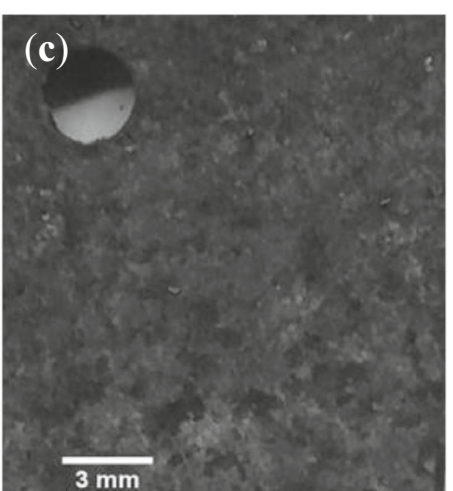

Superni 718

Figure 2. Photographs of the samples (Superni 75, Superni 750 and Superni 718) after 1000 h of oxidation in the secondary chamber of medical waste incinerator. 
(a)

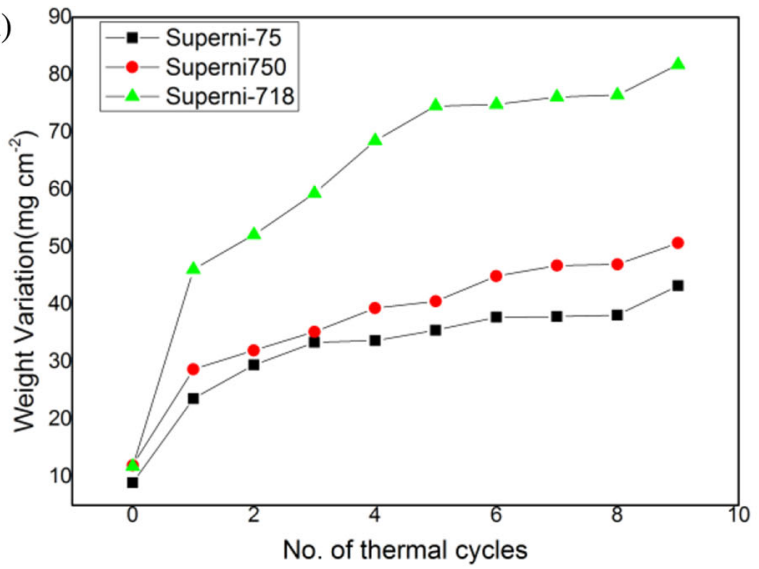

(b)

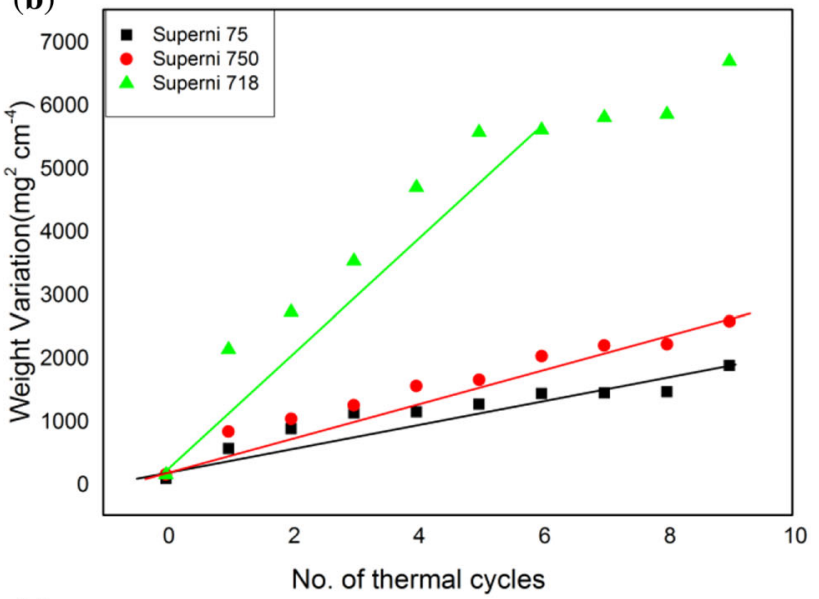

(c)

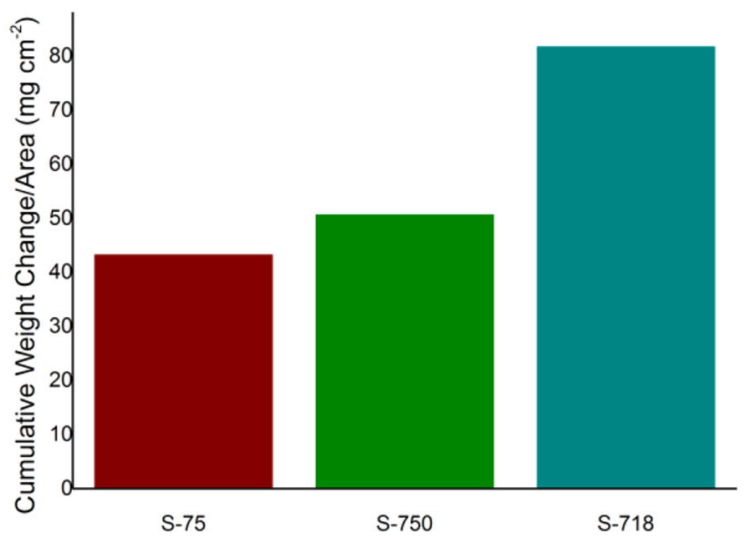

Figure 3. Weight Variation data for samples oxidized in medical waste incinerator environment for $1000 \mathrm{~h}$. (a) Weight change/area $\left(\mathrm{mg} / \mathrm{cm}^{2}\right)$ vs. number of cycles. (b) (Weight change/area) ${ }^{2}, \mathrm{mg}^{2} /$ $\mathrm{cm}^{4}$ versus number of cycles and (c) Cumulative weight gain/area $\left(\mathrm{mg} / \mathrm{cm}^{2}\right)$ versus number of cycles.

\section{$3.4 X R D$}

The XRD analysis of the corroded surface after $1000 \mathrm{~h}$ of exposure in medical waste incinerator has been shown in figure 5. Oxides such as $\mathrm{Cr}_{2} \mathrm{O}_{3}, \mathrm{Fe}_{2} \mathrm{O}_{3}, \mathrm{NiCr}_{2} \mathrm{O}_{4}$ and $\mathrm{TiO}_{2}$ were common in all the three superalloys. However in Superni 718, $\mathrm{NiCr}_{2} \mathrm{O}_{4}$ and $\mathrm{TiO}_{2}$ were present as a minor phase. The peaks of $\mathrm{Na}_{2} \mathrm{SO}_{4}, \mathrm{MgSiO}_{4}, \mathrm{CaCO}_{3}, \mathrm{CaSO}_{4}$ and $\mathrm{CaO}$ were also observed. These compounds indicate the ash deposition, as has been reported by Mudgal et al [4]. The municipal waste mainly comprises of silicon, aluminium, iron, magnesium, calcium, potassium, sodium and sulphur and $\mathrm{CaO}$ being the major compound [20]. An additional peak pertaining to $\mathrm{NbO}$ was found in Superni 718 and 750, whereas in Superni 75, NiO was observed. The results are in confirmation with the EDS which shows the presence of elements like $\mathrm{Cr}, \mathrm{Fe}, \mathrm{Ni}, \mathrm{Ti}$, oxygen, $\mathrm{S}, \mathrm{Ca}, \mathrm{Na}, \mathrm{Mg}$ and $\mathrm{Si}$. The spinel structures like $\mathrm{NiCr}_{2} \mathrm{O}_{4}$ enhance the oxidation resistance of material by retarding the diffusion of cations and anions [4].

\section{$3.5 X P S$}

The chemical compositions of the oxide scale were characterized by X-ray photoelectron spectroscopy (XPS) in the superficial layer. Figure 6 shows the XPS depth profile of the three oxidized superalloys. The decreasing trend of elements like $\mathrm{Ca}, \mathrm{Na}, \mathrm{Al}, \mathrm{Fe}$, oxygen and carbon, infers that these elements are present in the environment. The presence of $\mathrm{Ca}, \mathrm{Na}, \mathrm{Fe}, \mathrm{Al}$ indicates ash deposition [4]. Oxygen distribution is high at the surface in all the cases indicating the formation of oxide scale. The increasing trend shows substrate elements. On comparing the three superalloys, it can be observed that the trending lines are not sharp in Superni 750 and Superni 718. This indicates that the environmental elements are able to penetrate the substrate deeper as compared to Superni 75. Thus there has been cationic migration towards the oxide scale and anionic migration towards the substrate to a greater extent than $\mathrm{S}$ 75. The oxide scale formed in case of Superni 75 is more protective since it has been able to reduce the oxygen migration inwards and the migration of substrate elements (Ni, C, Ti) outwards.

\section{Discussion}

In the present study it was observed that the nickel-based superalloys have shown a good resistance in medical waste incinerator. This can be attributed to the presence of $\mathrm{NiCr}_{2} \mathrm{O}_{4}$ and $\mathrm{Cr}_{2} \mathrm{O}_{3}$. These impede the diffusion of the oxidizing species. $\mathrm{Cr}_{2} \mathrm{O}_{3}$ is mainly found to impart outstanding oxidation resistance in nickel-based superalloys [21]. The selective oxidation of $\mathrm{Cr}$ results in the formation of protective scale. Formation of $\mathrm{Cr}_{2} \mathrm{O}_{3}$ is favourable, the Gibbs free energy of $\mathrm{Cr}_{2} \mathrm{O}_{3}$ being more negative than other oxides of the metals present in the substrate [26]. Moreover $\mathrm{Cr}_{2} \mathrm{O}_{3}$ does not decompose significantly below $1000^{\circ} \mathrm{C}$ in oxidizing atmospheres [22].

Among the three grades, S 75 showed the best performance, as evident from the weight variation analysis, surface condition and chemistry of the scale. This may be 

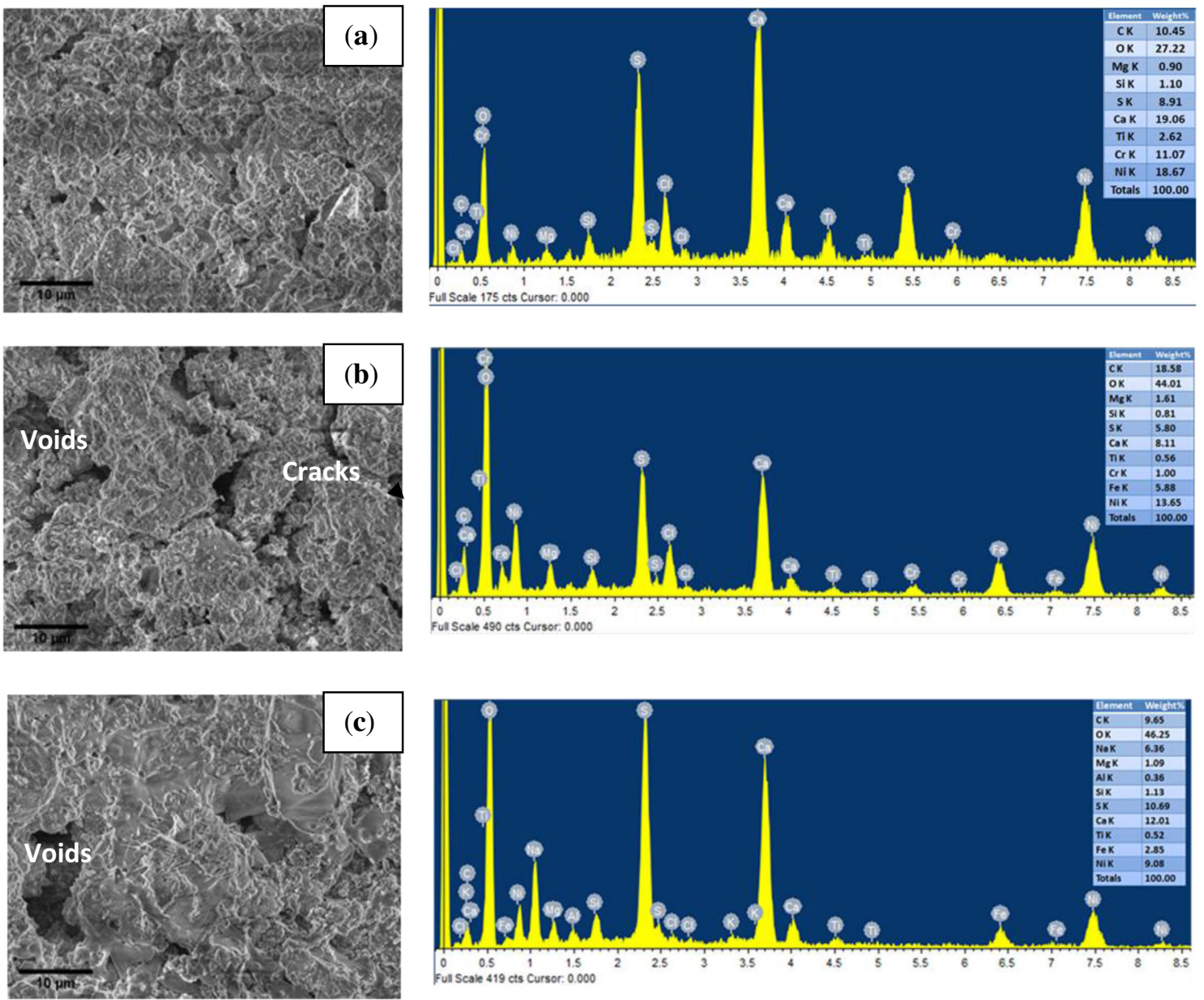

Figure 4. FEG-SEM/EDS of the oxidized samples, after oxidation in medical waste incinerator environment for $1000 \mathrm{~h}$. (a) Surface micrographs and chemical composition of the oxide layer formed on Superni-75. (b) Surface micrographs and chemical composition of the oxide layer formed on Superni-750. (c) Surface micrographs and chemical composition of the oxide layer formed on Superni-718

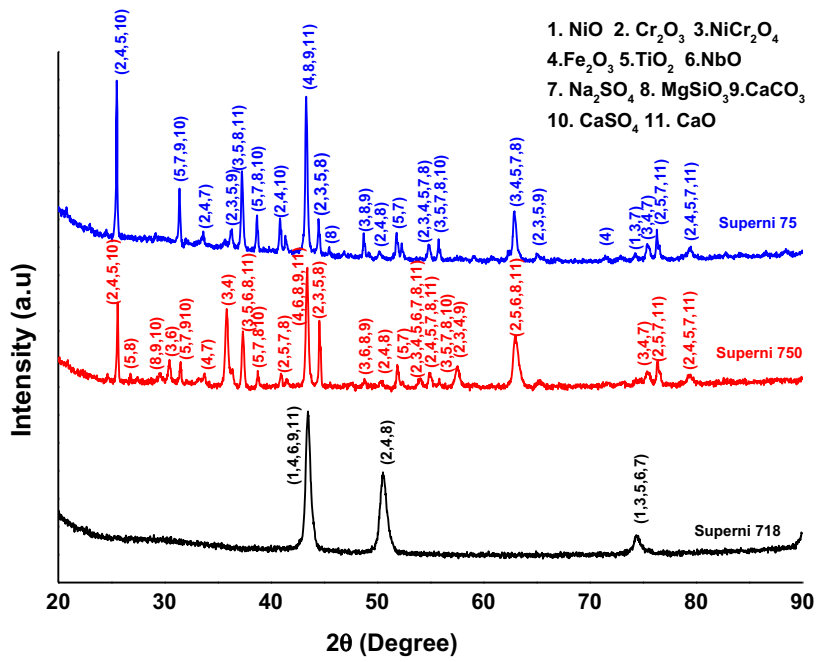

Figure 5. XRD patterns of oxidized the Superni 75, Superni 750 and Superni 718 samples hung in the secondary chamber of medical waste incinerator. attributed to the higher amount of both $\mathrm{Ni}$ and $\mathrm{Cr}$ in $\mathrm{S} 75$. Increasing the amount of $\mathrm{Ni}$ leads to an increase in the oxidation resistance and the chromium-rich oxides further improve the corrosion resistance of the materials [23-25]. Also in $\mathrm{S} \mathrm{75}$, the peak of $\mathrm{NiO}$ was observed in the XRD analysis. $\mathrm{NiO}$ has good protective properties [18].

The formation of $\mathrm{NiCr}_{2} \mathrm{O}_{4}$ and $\mathrm{Cr}_{2} \mathrm{O}_{3}$ can be shown as

$$
\begin{gathered}
\mathrm{Cr}+\mathrm{O}_{3}=\mathrm{Cr}_{2} \mathrm{O}_{3} \\
\mathrm{Cr}_{2} \mathrm{O}_{3}+\mathrm{NiO}=\mathrm{NiCr}_{2} \mathrm{O}_{4}
\end{gathered}
$$

The Ni-Cr alloys with low $\mathrm{Cr}$ show internal oxidation of $\mathrm{Cr}$. In this case $\mathrm{Cr}_{2} \mathrm{O}_{3}$ islands are formed in a matrix of $\mathrm{Ni}$ with islands of $\mathrm{NiCr}_{2} \mathrm{O}_{4}$. The mobility of $\mathrm{Ni}$ in this case is more. Any damage of the scale in this case leads to exposure of a lower $\mathrm{Cr}$ alloy, thus resulting in internal oxidation. Increasing the $\mathrm{Cr}$ content has a beneficial effect on the oxidation properties due to the depletion effect [26].

Species found in the present study such as $\mathrm{Al}, \mathrm{Ca}, \mathrm{Fe}, \mathrm{K}$, $\mathrm{Mg}$ and $\mathrm{Na}$ were also detected by Zhao et al in the bio- 

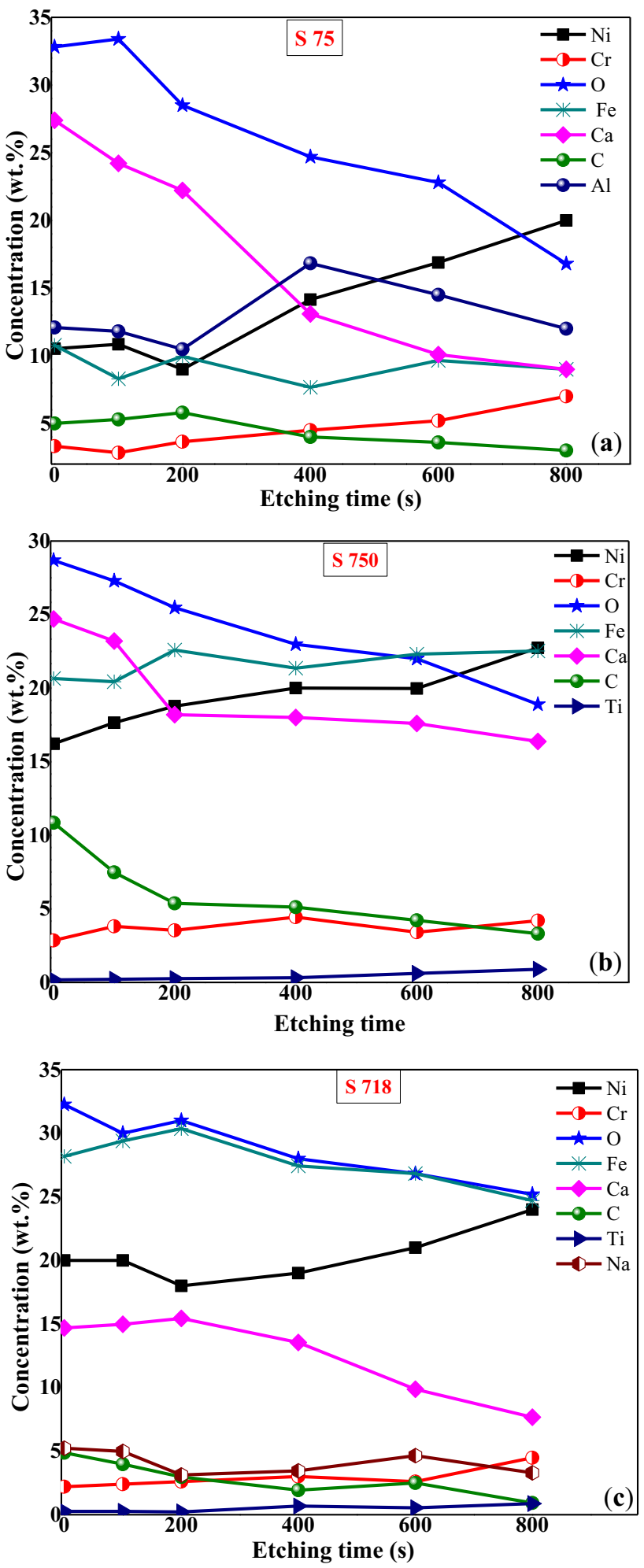

Figure 6. XPS analysis of the Superni 75, Superni 750 and Superni 718 samples hung in the secondary chamber of medical waste incinerator.

medical waste ash [27]. Elements like $\mathrm{S}, \mathrm{Cl}, \mathrm{Pb}, \mathrm{Zn}$ and $\mathrm{Sn}$ have been found to attack metals at high temperatures in the waste - energy conversion plants [5]. $\mathrm{CaSO}_{4}$ and $\mathrm{Na}_{2} \mathrm{SO}_{4}$ were detected in the XRD analysis. In molten sulphate medium, chromium oxide is contemplated to alleviate hot corrosion by preventing the diffusion of anions and the metallic cations [28-30]. Moreover, $\mathrm{Cr}_{2} \mathrm{O}_{3}, \mathrm{Al}_{2} \mathrm{O}_{3}$ and $\mathrm{SiO}_{2}$ possess a lower solubility in sulphate salt medium thus maintaining the corrosion resistant properties [31].

Indication of internal oxidation in all the three substrates was derived from the XPS depth profiling. However the trend-line pattern shows that the attack in case of Superni 75 is less severe as compared to Superni 750 and Superni 718. This can be justified because of the fact that higher Ni$\mathrm{Cr}$ content shows a better oxidation resistance.

Thus it can be summarized that in Superni 75 there is a presence of nickel and chromium just below the gray layer of ash. The thick oxide scale consists of nickel and chromium-rich spinels and chromium-rich protective oxide as well as nickel oxide. The formation of these oxides is favourable as depicted in the Ellingham diagram. These are responsible for imparting the oxidation resistance in this superalloy.

Species from the environment like oxygen, $\mathrm{Na}, \mathrm{Ca}, \mathrm{Fe}$, etc. have been able to enter the sub-surface but unable to penetrate deeper because of the low diffusivity in the spinel structures.

In the case of Superni 750 and 718 , the scale having voids and cracks is less protective as the diffusion through irregularities is more. Thus the environmental elements have been able to penetrate the subscale more than Superni 75.

\subsection{Mechanism}

Based on the above discussion, a mechanism has been devised. The substrate elements like $\mathrm{Ni}, \mathrm{Fe}, \mathrm{Cr}, \mathrm{Nb}$ form respective oxides in the medical waste incinerator at 800 $850^{\circ} \mathrm{C}$ in the following way:

$$
\begin{aligned}
\mathrm{Ni}+1 / 2 \mathrm{O}_{2} & =\mathrm{NiO} \\
4 \mathrm{Fe}+3 \mathrm{O}_{2} & =2 \mathrm{Fe}_{2} \mathrm{O}_{3} \\
4 \mathrm{Cr}+3 \mathrm{O}_{2} & =2 \mathrm{Cr}_{2} \mathrm{O}_{3} \\
\mathrm{Ti}+\mathrm{O}_{2} & =\mathrm{TiO}_{2}
\end{aligned}
$$

The elements from the environment like $\mathrm{Na}, \mathrm{S}, \mathrm{Na}, \mathrm{Ca}$ form oxides as shown in the following reactions:

$$
\begin{gathered}
\mathrm{S}+\mathrm{O}_{2}=\mathrm{SO}_{2} \\
\mathrm{SO}_{2}+1 / 2 \mathrm{O}_{2}=\mathrm{SO}_{3} \\
2 \mathrm{Na}+1 / 2 \mathrm{O}_{2}=\mathrm{Na}_{2} \mathrm{O} \\
\mathrm{Ca}+1 / 2 \mathrm{O}_{2}=\mathrm{CaO}
\end{gathered}
$$

The $\mathrm{SO}_{3}$ and $\mathrm{Na}_{2} \mathrm{O}$ react to form $\mathrm{Na}_{2} \mathrm{SO}_{4}$ as shown below: 


$$
\mathrm{SO}_{3}+\mathrm{Na}_{2} \mathrm{O}=\mathrm{Na}_{2} \mathrm{SO}_{4}
$$

Also $\mathrm{SO}_{3}$ may react with the $\mathrm{NaCl}$ from present in the medical waste and form $\mathrm{Na}_{2} \mathrm{SO}_{4}$ as:

$$
\mathrm{SO}_{3}+2 \mathrm{NaCl}+2 \mathrm{H}_{2} \mathrm{O}=\mathrm{Na}_{2} \mathrm{SO}_{4}+4 \mathrm{HCl}
$$

$\mathrm{Na}_{2} \mathrm{SO}_{4}$ is a low melting compound. $\mathrm{NaCl} / \mathrm{Na}_{2} \mathrm{SO}_{4}$ form a eutectic mixture having a melting point less than $800^{\circ} \mathrm{C}$. Studies of hot-corrosion induced by mixtures of $\mathrm{NaCl} /$ $\mathrm{Na}_{2} \mathrm{SO}_{4}$ on Fe-base alloys has shown that this mixture can easily degrade the protective $\mathrm{Cr}_{2} \mathrm{O}_{3}$ layers on the AISI 310 at $750^{\circ} \mathrm{C}$ [32].

Penetration of the eutectic salt mixture through the protective scale causes it to contact the substrate, thus leading to loss of the substrate elements. This is known as hot corrosion.

During the initial stages, Superni 718 exhibits increase in the weight up to $100 \mathrm{~h}$, owing to the formation of a protective oxide scale (figure $3 \mathrm{a}$ ). After $100 \mathrm{~h}$ to $500 \mathrm{~h}$ continuous degradation of the alloy occurs due to the fluxing of the scale. The $\mathrm{Ni}-\mathrm{Cr}$ spinel phase having a melting point of $950^{\circ} \mathrm{C}$ interrupts the action of the eutectic mixture as in equation (2). Thus there is a constant weight variation between 500 and $800 \mathrm{~h}$. The formation of spinel pahse may be due to the dissolution of $\mathrm{Cr}_{2} \mathrm{O}_{3}$ and $\mathrm{NiO}$ in the molten salt of sodium sulphate and $\mathrm{NaCl}$. However, the spinel phase is irregular on the surface as it is shown as a minor phase in the XRD. The similar observations were reported by Sadique et al [33].

In case of Superni 750 and 75 , the weight variation during the initial stages is less, it might be due to the protective oxide scale having sufficient amount of the $\mathrm{Ni}-\mathrm{Cr}$ spinel phase, as observed in the XRD. Among the three, Superni 75 exhibits the least weight variation. From the FESEM micrograph it can be observed that the scale is free from cracks and spallation. Also the number of voids in Superni 75 is very less as compared to Superni 750 and 718. This might be attributed to the spinel phase that blocks the possible path for the diffusion of the environment into the substrate, thus reducing the overall weight variation.

The cracks are developed in the scale due to the stress in the scale-base metal interface during cooling as a result of thermal expansion mismatch. The corrosive environment is able to enter through these cracks and reach the base metal. This results in adhesion loss and spalling of the scale [34].

\section{Conclusion}

The aim of the present investigation was to elucidate the difference in oxidation behavior of three nickel-based superalloys - Superni 75, 750 and 718 in the secondary chamber of a medical waste incinerator for $1000 \mathrm{~h}$, where the temperature is about $800-850^{\circ} \mathrm{C}$. The materials are exposed to a heterogeneous type of waste in the medical waste incinerator.

The following were the main observations of the present study:

- In general, the nickel based superalloys are suitable for the incinerator environment. Superni 75 displayed the best corrosion resistance among the three nickel-based superalloys in the present in-situ study.

- The hot corrosion resistance of the superalloys is in the following order:

- Superni $75>$ Superni $750>$ Superni 718 .

- Ash deposition was observed in all the cases, as is evident from the EDS, XRD and XPS analysis.

- The excellent properties of the Superni75 in such an environment can be attributed to the presence of spinel $\mathrm{NiCr}_{2} \mathrm{O}_{4}$ and chromia oxide- $\mathrm{Cr}_{2} \mathrm{O}_{3}$ in defect-free scale.

\section{References}

[1] Hunsicker M D, Crockett T R and Labode B M A 1996 An overview of the municipal waste incineration industry in Asia and the former Soviet Union. J. Hazard Mater. 47: $31-42$

[2] Hassan M M, Ahmed S A, Rahman K A and Biswas T K 2008 Pattern of medical waste management: Existing scenario in Dhaka City, Bangladesh. BMC Public Health 8: $36-46$

[3] Singh H, Sidhu T S, Karthikeyan J and Kalsi S B S 2015 Evaluation of characteristics and behavior of cold sprayed $\mathrm{Ni}-20 \mathrm{Cr}$ coating at elevated temperature in waste incinerator plant. Surf. Coat. Technol. 261: 375-384

[4] Mudgal D, Ahuja L, Bhatia D, Singh S and Prakash S 2016 High temperature corrosion behaviour of superalloys under actual waste incinerator environment. Eng. Fail. Anal. 63: 160-171

[5] Krause H H 1986 High temperature corrosion problems in waste incineration systems. J. Mater. Energy Syst. 7: 322-332

[6] Ni M, Du Y, Lu S, Peng Z, Li X, Yan J and Cen K 2013 Study of ashes from a medical waste incinerator in China: Physical and chemical characteristics on fly ash, ash deposits and bottom ash. Environ. Prog. Sustain. Energy 32: 496-504

[7] Weulersse K, Moulin G, Billard P and Pierotti G 2004 High Temperature corrosion of superheater tubes in waste incinerators and coal-fired plants. Mater. Sci. Forum 461-464: 973-980

[8] Uusitalo M, Vuoristo P M and Mäntylä T 2004 High temperature corrosion of coatings and boiler steels below chlorine-containing salt deposits Corros. Sci. 46: 1311-1331

[9] Klenowicz Z and Darowicki K 2001 Waste incinerators: corrosion problems and construction materials-a review. Corros. Rev. 19: 467-491

[10] Otero E, Pardo A, Merino M C, Utrilla M V, Lopez M D and Peso J L D 1999 Corrosion behavior of IN-800 superalloy in waste-incineration environments. Oxid. Met. 51: 507-525 
[11] Mudgal D, Singh S and Prakash S 2014 Hot corrosion behavior of some superalloys in a simulated incinerator environment at $900^{\circ}$ C. J. Mater. Eng. Perform. 23: 238-249

[12] Sidhu T S, Malik A, Prakash S and Agrawal R D 2006 Cyclic oxidation behavior of $\mathrm{Ni}$ - and $\mathrm{Fe}$ based superalloys in air and $\mathrm{Na}_{2} \mathrm{SO}_{4}-25 \% \mathrm{NaCl}$ molten salt environment at $800^{\circ} \mathrm{C}$. Int . J. Phys. Sci. 1: 27-33

[13] Uusitalo M, Vuoristo P M and Mäntylä T 2002 High temperature corrosion of coatings and boiler steels below in reducing chlorine-containing atmosphere. Surf. Coat. Technol. 161: 275-285

[14] Rahman A, Jayaganthan R, Chandra R and Ambardar R 2013 High temperature degradation behavior of sputtered nanostructured Co-Al coatings on superalloy. Appl. Surf. Sci. 265: $10-23$

[15] Rahman A, Chawla V, Jayaganthan R, Chandra R and Ambardar R 2011 Study of cyclic hot corrosion of nanostructured $\mathrm{Cr} / \mathrm{Co}-\mathrm{Al}$ coatings on superalloy. Mater. Chem. Phys. 126: 253-261

[16] Rahman A, Chawla V, Jayaganthan R, Chandra R and Ambardar R 2010 Evaluation of high temperature oxidation behaviour of nanostructured $\mathrm{Cr} / \mathrm{Co}-\mathrm{Al}$ coatings. Oxid Met. 74: $341-358$

[17] Rahman A, Jayaganthan R, Chandra R and Ambardar R 2011 Microstructural characterization and cyclic hot corrosion behaviour of sputtered $\mathrm{Co}-\mathrm{Al}$ nanostructured coatings on superalloy. Oxid Met. 76: 307-330

[18] Ishitsuka T and Nose K 2002 Stability of protective oxide films in waste incineration environment-solubility measurement of oxides in molten chlorides. Corros. Sci. 44: 247-263

[19] El-Awadi G A, Abdel-Samad S and Elshazly E S 2016 Hot corrosion behavior of $\mathrm{Ni}$ based Inconel 617 and Inconel 738 superalloys. Appl. Surf. Sci. 378: 224-230

[20] Lam C H K, Ip AWM, Barford J P and Mckay G 2010 Use of incineration MSW ash: A review. Sustainability 2: 1943-1968

[21] Karabela A, Zhao L G, Tong J, Simms N J, Nicholls J R and Hardy M C 2011 Effects of cyclic stress and temperature on oxidation damage of a nickel-based superalloy. Mater. Sci. Eng. A 528: 6194-6202

[22] Vasantasree V and Hocking M G 1976 Hot corrosion of Ni$\mathrm{Cr}$ alloys in $\mathrm{SO}_{2}+\mathrm{O}_{2}$ atmospheres-I. Corrosion kinetics. Corros. Sci. 16: 261-277
[23] [23] Haanappel V A C, Fransen T and Gellings P J 1992 Chlorine-induced high temperature corrosion: I. Metals and alloys-A review. High Temp. Mater. Processes. 10: 67-89

[24] Li Y S, Niu Y and Wu W T 2003 Accelerated corrosion of pure $\mathrm{Fe}, \mathrm{Ni}, \mathrm{Cr}$ and several $\mathrm{Fe}$-based alloys induced by $\mathrm{ZnCl}_{2}-\mathrm{KCl}$ at $450^{\circ} \mathrm{C}$ in oxidizing environment. Mater. Sci. Eng. A. 345: 64-71

[25] Guilemany J M, Torrell M and Miguel J R. Study of the HVOF Ni-based coatings' corrosion resistance applied on municipal solid-waste incinerators. J. Therm. Spray Technol. 17: 254-262

[26] Birks N, Meier G and Pettit F 2006 Oxidation of alloys introduction to high temperature oxidation of metals, chapter 5, 2nd edition. Cambridge: Cambridge University Press, pp. 116-119

[27] Zhao L, Zhang F S and Zhang J 2008 Chemical properties of rare earth elements in typical medical waste incinerator ashes in China. J. Hazard. Mater. 158: 465-470

[28] Mudgal D, Kumar S, Singh S and Prakash S. 2014 Corrosion behaviour of bare, $\mathrm{Cr}_{3} \mathrm{C}_{2}-25 \%(\mathrm{NiCr})$, and $\mathrm{Cr}_{3} \mathrm{C}_{2}-25 \%$ $(\mathrm{NiCr})+0.4 \% \mathrm{CeO}_{2}$-coated Superni 600 under molten salt at $900^{\circ}$ C. J. Mater. Eng. Perform. 23: 3805-3818

[29] Mudgal D, Singh S and Prakash S 2015 Hot corrosion behaviour of Bare, $\mathrm{Cr}_{3} \mathrm{C}_{2}-(\mathrm{NiCr})$ and $\mathrm{Cr}_{3} \mathrm{C}_{2}-(\mathrm{NiCr})+0.2$ wt.\% $\mathrm{Zr}$ coated SuperNi 718 at $900^{\circ} \mathrm{C}$, J. Mater. Eng. Perform. 24: 1-15

[30] Mudgal D, Singh S and Prakash S 2015 Evaluation of ceria added $\mathrm{Cr}_{3} \mathrm{C}_{2}-25(\mathrm{NiCr})$ coating deposit on three superalloys under simulated incinerator environment. J. Therm. Spray Technol. 24: 496-514

[31] Bradshaw A, Simms N J and Nicholls J R 2013 Development of hot corrosion resistant coatings for gas turbines burning biomass and waste derived fuel gases. Surf. Coat. Technol. 216: 8-22

[32] Sarvghad M, Geoffrey W and Steinberg T 2017 Corrosion of steel alloys in molten $\mathrm{NaCl}+\mathrm{Na}_{2} \mathrm{SO}_{4}$ at $700^{\circ} \mathrm{C}$ for thermal energy storage. Sol. Energy Mater. Sol. C 179: 207-216

[33] Sadique S E, Mollah A H, Islam M S, Ali M M, Megat M H $\mathrm{H}$ and Basri S 2000 High-temperature oxidation behavior of iron-chromium-aluminum alloys. Oxid. Met. 54: 385-400

[34] Wang D 1988 Corrosion behavior of chromized and/or aluminized 214Cr-1Mo steel in medium-BTU coal gasifier environments. Surf. Coat. Technol. 36: 49-60 